UDK 378.147:51

DOI: $10.24045 /$ pp.2017.3.7

\title{
EFFECTIVENESS OF MEDICAL STUDENTS' MATHEMATICAL COMPETENCE FORMATION THROUGHOUT E-LEARNING PROCESS
}

L. V. Snegireva

\author{
Candidate of Biological Sciences \\ assistant professor \\ Kursk State Medical University \\ Kursk, Russia
}

\begin{abstract}
The article analyzes the mathematical competence structural components acquisition and development throughout the mathematics e-learning process, as e-learning role is also studied in terms of the medical university students' mathematical competence formation. Based on experimental data, the author made the scientific assessment of the mathematical competence main structural components at different stages of medical university mathematics e-learning process. The author shows that usage of modern information learning technologies in educational process can actively influence on the acquisition and development of mathematical competence basic structural components, promoting the formation of medical university students' willingness and abilities to solve theoretical and practical problems that are relevant to the professional activities of a modern medical profile specialist.
\end{abstract}

Keywords: e-learning; mathematical competence; model; high education; the main structural components.

The mathematical competence concept is considered from different points of view by modern researchers $[1,2]$. To the author' opinion, the most accurate definition of mathematical competence is: an integral personal quality, readiness to study disciplines requiring mathematical base, ability to use mathematical knowledge in professional activity for various practical and theoretical problems solving [4]. In accordance with the definition, mathematical competence is multicomponent concept with multilevel structure. Its formation is the process of acquiring and developing various structural components. That is why; the development of mathematical competence model regarding its main structural components is the important problem of modern pedagogical science. To solve it, the author singled out the main (from his point of view) mathematical competence structural 
components, namely: the readiness and ability in practical and theoretical problems to analysis and synthesis, to abstraction from the nonessential properties and objects and phenomena characteristics, to generalization. A three-dimensional mathematical competence model representation is shown in Fig 1.

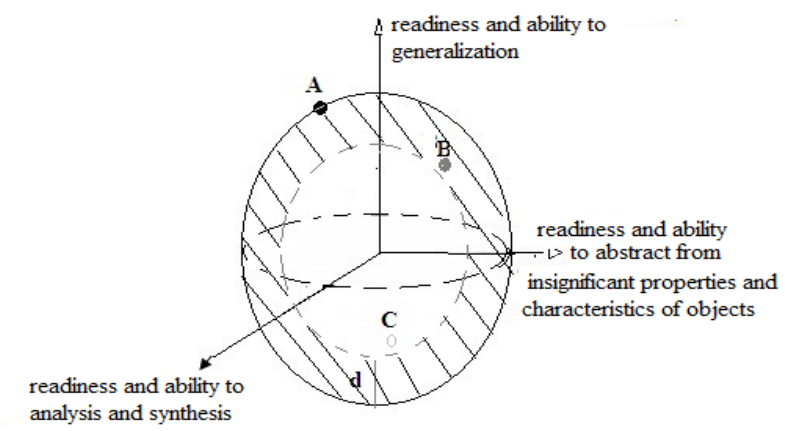

Figure 1. Three-dimensional representation of model of mathematical competence.

Note: the area designated by shading on the sphere designates the level of mathematical competence of pupils conforming to requirements of the federal state educational standard.

Points of the sphere surface (for example, point $\mathrm{A}$ ) in the coordinates of the mathematical competence basic structural components indicate the federal state educational standard mathematical competence level for medical university students. The goal of university educational process is to achieve the federal standard mathematical competence level. It should be noted that, sometimes, medical university students don't achieve the required mathematical competence level (shown on our model by point A) due to various reasons, ranging from low students' motivation and lack of their self-organization, to insufficient educational and cognitive trainees' activity. In this case the mathematical competence components acquisition stops at the respectively low level (shown as point B inside the sphere in Figure 1). For this reason, there is a real need in educational tool that can increase the medical students' motivation, improve the university students' individual work organization and self-control function. To our opinion, e-learning can be considered as such effective

Paradigmata poznání. 3. 2017 
educational tool (instrument) at the modern conditions $[3,5,6]$.

In this regard, the present research aim was defined as studying the elearning role in mathematical competence basic structural components formation for medical students. The cognitive activity results of clinical psychology faculty students were chosen as an object of the study.

The research tasks are:

- to study clinical psychology faculty students mathematical competence level at the initial stage of mathematics e-learning;

- to analyze clinical psychology faculty students mathematical competence level at the final stage of mathematics e-learning.

Materials and methods.

The testing of 30 first-year and second-year clinical psychology students was carried out. First-year students were tested as the starters of mathematics e-learning. Second-year clinical psychology faculty students were involved into mathematical elearning testing after passing the mathematical course examination. The experiment was held in constant conditions for both groups of students: the research was held at 11 a.m. in the academic auditory. The research duration was about 50 minutes. The clinical psychology faculty students performed the testing independently without using any electronic devices. The testing was built on the basis of Atmhauer intelligence structure test including the scale of mathematical abilities determination and a questionnaire "Thinking type".

Table 1 represents first-year students' mathematical competence level at the mathematics e-learning initial stage. Medical students' basic structural components formation was esteemed, and the clinical psychology faculty students were distributed between four groups according to their mathematical competence level: high, medium, medium-low and low.

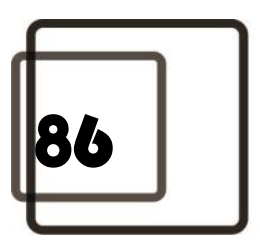


The first-year students' mathematical competence level at the mathematics e-learning initial stage

\begin{tabular}{|l|r|r|l|}
\hline \multirow{2}{*}{} & \multicolumn{3}{|c|}{ Main structural components of mathematical competence } \\
\cline { 2 - 4 } & \multicolumn{3}{|c|}{ ability } \\
\cline { 2 - 4 } Level & $\begin{array}{l}\text { to analysis } \\
\text { and synthe- } \\
\text { sis }\end{array}$ & $\begin{array}{l}\text { to general- } \\
\text { ization }\end{array}$ & $\begin{array}{l}\text { to abstraction from objects' insignificant } \\
\text { properties and characteristics }\end{array}$ \\
\hline high & $7 \%$ & $14 \%$ & $0 \%$ \\
\hline average & $29 \%$ & $29 \%$ & $7 \%$ \\
\hline average - low & $29 \%$ & $36 \%$ & $43 \%$ \\
\hline low & $35 \%$ & $21 \%$ & $50 \%$ \\
\hline
\end{tabular}

As shown from Table 1, $7 \%$ of the first-year examinees confidently coped with tasks, demonstrating high level of analytical abilities development. High level of abstract thinking development was not found among the students at mathematics e-learning initial stage. And $14 \%$ of the first-year examinees showed highly developed abilities to identify significant relationships within the whole.

According to the test results, twothirds of the first-year students confidently took a place in the group with an average and average -low level of ability to systematize objects or phenomena properties. Average and average -low levels of mathematical abilities for analysis and synthesis were demonstrated by $58 \%$ of examinees. And exactly half of the first-year students were assigned to the group with average and average-low levels of ability to translate information about real objects into symbols.

$50 \%$ of the first-year students got into a group with low level of abstract thinking development at the initial stage of mathematics e-learning. They had problems with abstract symbols and concepts operations. $21 \%$ of examinees demonstrated difficulties in determining subject's common features by comparison, that was 2.4 times less than in previous group. About a third of the first-year students showed low level of analytical and synthetic abilities development.

To summarize results, we simulated the mathematical competence initial level as a set of points within the sphere, coordinated according to the level of development of abilities to analyze and synthesize, generalize, abstract from nonessential objects and phenomena properties and characteris- 
tics. It is important to note, the sphere standard as the result of mathematics surface points represent the mathemat- studying (Figure 2). ical competence level of educational

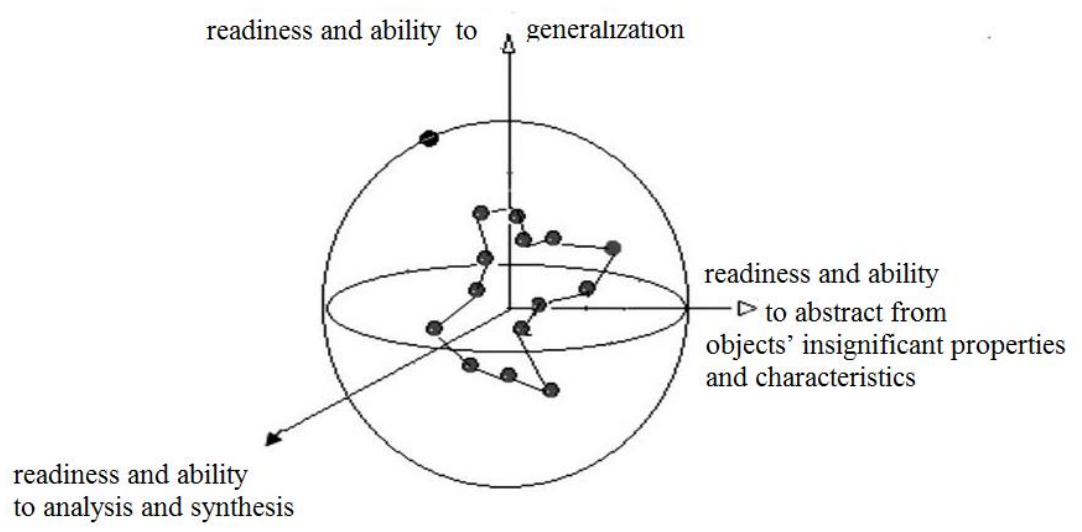

Figure 2. The first-year students' mathematical competence level at the mathematics e-learning initial stage.

Note: black points within the sphere designate the level of mathematical competence.

At the next stage of our research, ed student's knowledge at the final first-year students began mathematics stage of mathematics e-learning. The e-learning to acquire and develop research results showed, that mathemathematical competence basic struc- matics e-learning made it possible to tural components. To assess the e- increase the number of students with learning effectiveness in the mathe- high level of abilities for analysis and matical competence formation we test- synthesis from $7 \%$ to $13 \%$. (Table 2). 
Medical students' mathematical competence level at the mathematics e-learning final stage

\begin{tabular}{|c|c|c|c|}
\hline \multirow[b]{2}{*}{ Level } & \multicolumn{3}{|c|}{ Main structural components of mathematical competence } \\
\hline & $\begin{array}{l}\text { to analysis } \\
\text { and syn- } \\
\text { thesis }\end{array}$ & \begin{tabular}{|l} 
to general- \\
ization
\end{tabular} & \begin{tabular}{|l|} 
ability \\
to abstraction from objects' insignifi- \\
cant properties and characteristics
\end{tabular} \\
\hline high & $13 \%$ & $38 \%$ & $0 \%$ \\
\hline average & $38 \%$ & $31 \%$ & $19 \%$ \\
\hline average - low & $44 \%$ & $13 \%$ & $50 \%$ \\
\hline low & $5 \%$ & $18 \%$ & $31 \%$ \\
\hline
\end{tabular}

The tendency of mathematical abilities development in e-learning process was found also in the component "readiness and ability to generalize". For this indicator, the most significant growth was observed. The fourth part of examinees joined the group with a high level of ability to mentally unite various objects, phenomena and concepts according to the most significant features.

At the e-learning final stage it was declined in the number of students, initially demonstrating a low level of mathematical skills development. The most significant progress was observed in the indicator "readiness and ability to analyze and synthesize". The number of examinees with difficulties in analytical activities has decreased from $35 \%$ to $5 \%$ in the mathematics e-learning process. Mathematics elearning was effective in mathematical competence formation, particularly in the development of such a component as "readiness and the ability to abstract from the non-essential objects and phenomena properties and characteristics." We noted a significant decrease in the number of students with a low level of ability to transfer information about real objects into symbols. Almost a fifth part of examinees got a higher level of abilities to carry out operations with abstract symbols and concepts. The number of students with low level of ability to manipulate symbols has decreased from $50 \%$ to $31 \%$. Difficulties were mostly found in development of mathematical competence component "readiness and ability to generalize," although positive dynamics in ability formation was observed in the e-learning process. The number of students having problems in systemizing object and phenomena features was reduced from $21 \%$ to $18 \%$. However, (from Ta- 
ble. 2), progress was not as significant as for the other indicators. It should be noted that, decrease in the number of students with a low level of analytical and synthetic skills development, caused the expansion of the groups with average and average -low abilities for analysis and synthesis (from $58 \%$ to $82 \%$ ). Mathematics e-learning allowed improving the mathematical skills for the fourth part of examinees. At the same time, the number of students with average ability to determine the general features in a number of objects by comparison increased from $29 \%$ to $31 \%$. The mathematical competence model shown in Fig. 3, demonstrates the real progress in each of the structural components at the final stage of e-learning process.

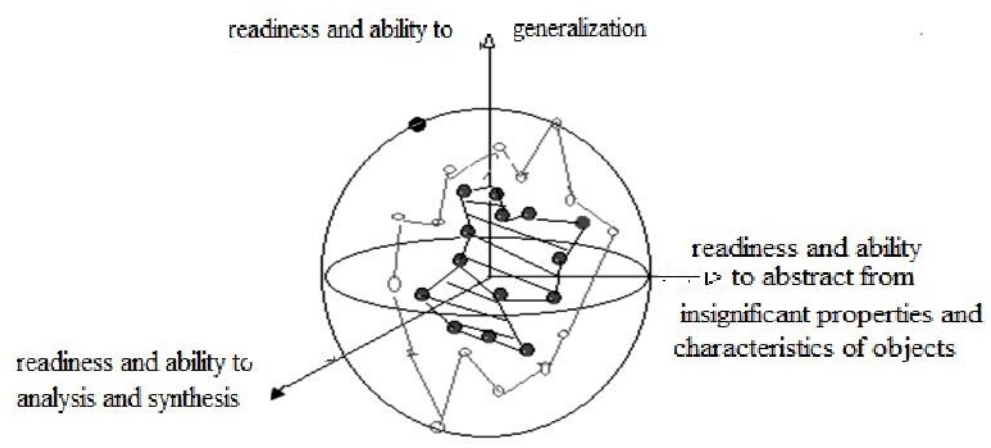

Figure 3. Mathematical competence model for clinical psychology faculty students' mathematical competence level at the mathematics e-learning final stage.

Note: black points within the sphere designate the level of mathematical competence at the mathematics e-learning initial stage, white points within the sphere designate the level of mathematical competence at the mathematics e-learning final stage

We think that the proposed model is useful in evaluating students' learning activity result. It can serve as an indicator of each structural components formation effectiveness and mathematical competence development. Model can be used as a measurement instrument of efficiency level for educational technologies. In our study, all considered indicators are evidence of e-learning effectiveness in the mathematical competence formation. We hope, this fact will serve as a base for the further development of e-learning. 


\section{Bibliography}

1. Байгушева И. А. Формирование математической компетентности экономистов в вузе // Современные проблемы науки и образования. - 2012. - № 1; URL: http:// scienceeducation.ru/ru/article/view?id=5543 (дата обращения: 28.05.2016).

2. Бурова А. В. Формирование когнитивных умений у учащихся основной школы при выполнении домашней работы по физике : автореф. дис. ... канд. пед. наук. - Курск, 2010.

3. Емельянова Е. Ю. Использование информационных технологий в процессе адаптации студентов младших курсов // Вестник Московского городского педагогического университета. Серия: Информатика и информатизация образования. - 2006. - № 2. - С. 70.

4. Синицын И. С. Формирование математической компетентности студентовгеографов на основе прикладных задач // Ярославский педагогический вестник. - 2014. - № 3. - Том II (Психолого-педагогические науки). C. $105-110$.

5. Снегирева Л. В. Развитие абстрактного мышления студентов-медиков в процессе электронного обучения математике //Азимут научных исследований: педагогика и психология. - 2016. № 2 (15), - T. 5. - С. 143-146.

6. Снегирева Л. В. Электронное обучение в формировании математических способностей студентов медицинского вуза // Современные проблемы науки и образования. - 2016. - № 3. URL: https://science-

education.ru/ru/article/view $\mathrm{id}=24493$

(дата обращения: 04.02.2017).

\section{Bibliography}

1. Bajgusheva I. A. Formirovanie matematicheskoj kompetentnosti jekonomistov v vuze // Sovremennye problemy nauki i obrazovanija. - 2012. № 1 ; URL: http:// scienceeducation.ru/ru/article/view?id=5543 (data obrashhenija: 28.05.2016).

2. Burova A. V. Formirovanie kognitivnyh umenij u uchashhihsja osnovnoj shkoly pri vypolnenii domashnej raboty po fizike : avtoref. dis. ... kand. ped. nauk. Kursk, 2010.

3. Emel'janova E. Ju. Ispol'zovanie informacionnyh tehnologij $\mathrm{v}$ processe adaptacii studentov mladshih kursov // Vestnik Moskovskogo gorodskogo pedagogicheskogo universiteta. Serija: Informatika i informatizacija obrazovanija. - 2006. - № 2. - S. 70.

4. Sinicyn I. S. Formirovanie matematicheskoj kompetentnosti studentov-geografov na osnove prikladnyh zadach // Jaroslavskij pedagogicheskij vestnik. - 2014. № 3. - Tom II (Psihologopedagogicheskie nauki). - S. 105-110.

5. Snegireva L. V. Razvitie abstraktnogo myshlenija studentov-medikov $\mathrm{v}$ processe jelektronnogo obuchenija matematike // Azimut nauchnyh issledovanij: pedagogika i psihologija. - 2016. - № 2 (15). - T. 5. - S. 143-146.

6. Snegireva L. V. Jelektronnoe obuchenie v formirovanii matematicheskih sposobnostej studentov medicinskogo vuza// Sovremennye problemy nauki i obrazovanija. - 2016. - № 3. URL: https://scienceeducation.ru/ru/article/view?id=24493 (data obrashhenija: 04.02.2017). 